\title{
Architectural Space as a Factor of Regional Cultural Identity
}

\author{
Anastasia V. Kistova* and Anastasia N. Tamarovskaya \\ Siberian Federal University \\ 79 Svobodny, Krasnoyarsk, 660041, Russia
}

Received 20.09.2014, received in revised form 09.11.2014, accepted 20.12.2014

\begin{abstract}
The provisions stated in the paper are based on findings of modern cultural and art studies related to the ability of architectural spaces to form a concept of oneself, of a society, of the world for a human being, who is interacting with these spaces. Only true architectural masterpieces of the state-of-art type are able to produce a positive impact on the cultural identity of a person when forming the architectural artistic image.

The article also contains the results of research of Krasnoyarsk Church of the Miracle of the Archangel Michael at Chonae as an example of church architecture of regional importance, able to form a positive cultural identity, and the results of practical research of the peculiarities of perception of the architecture by children in primary and secondary school. The research was conducted by Anastasia Tamarovskaya, a fourth-year student majoring in "history of arts" at the Institute for Humanities of Siberian Federal University.
\end{abstract}

Keywords: Regional cultural identity, architectural space, piece of architecture, architectural artistic image, perception of architecture by children, Krasnoyarsk architecture, Church of the Miracle of the Archangel Michael at Chonae (Colossae).

Research area: culture studies, art history.

\section{Introduction}

The relevance of the impact of architectural spaces and forms on a person's cultural identity is increasingly mentioned in the articles of modern architecture researchers (K. Higa, 2013; K.M. Kuenzli, 2012; P. Schumacher, 2009; C. Whiting, 2011; S.T. Agisheva, F.D. Mubarakshina, 2013; S.Yu. Alexeev, N.N. Alexeeva, 2013; T.Yu. Bistrova, 2010; E.Yu. Vituk, 2012; Yi.A. Ibragimov, 2009; V.O. Karovsky, 2012; K. Kelly, 2011 et all.) and cultural identity researchers (C.M.S.Johns, 2004; J.V. Maciuika, 2005; M.M. Reeve,
2013; J. Shannon., 2012; G.M. Thomas, 2009; O.N. Astafieva, 2010; D.S. Gavrikov, 2012; A.Yi. Gromnuk, 2012; O.E. Zhelezniak, G.Yi. Okhrimenko, 2009; D.A. Leontiev, 2009 et all), who seem to be working in different areas, but come to general conclusions about the significance of the impact of architectural forms and spaces for the formation of the picture of the world for a man, as well as the opposite impact of human outlook on the emergence and development of architectural works and architectural environment. Architecture, considered at the intersection of cultural studies, aesthetics,

(C) Siberian Federal University. All rights reserved

* Corresponding author E-mail address: kistochka7@mail.ru 
philosophy, sociology and psychology, begins to be understood as human living space, formed by human and forming human: "The presence of the designer's perceived philosophical and ideological basis not only ensures the integrity of the architectural and urban solutions, but also the intensity of exposure on the perceiver. Setting definite visual and behavioral scenarios, the decision slowly and constantly moves human closer to cultural traditions, contributing to socialization and reflection. Perceiving the objects as our "own", we may not think about their semantics and focus, but we feel our unity or diversity with them" (T.Yu. Bistrova, 2010, 129-130).

Such a representation of the architecture in its symbiotic relationship with the man is explained by researchers as "re-estimation of values in the structure of modern society, where the priority is given to the notion of personal space, freedom of choice and access to information" (N.A. Mityashina). Such a formulation of the problem involves a high degree of awareness in the design of architectural works and spaces, as well as raises the question about their perception by people living and working in these spaces (V.Yi. Vetoshkin, 2010; N.V. Lamekhova, 2009; A.V. Lobanov, 2008; T.P. Nesterova, 2010; Yi.E. Nikitina, L.A. Shtompel, 2011; A.B. Permilovskaya, 2011; M.V. Puchkov, 2013; A.S. Tokarev, 2006 et all).

This means, first, that not every architectural structure really is able to form a coherent and harmonious image of a man inscribed in the cultural traditions of society and able to perceive ideals respectful of other cultures. Only those facilities which according to the tradition usually called masterpieces of art fully have the property of forming the cultural identity. Facilities which were created excluding this impact on human architectural forms, as well as an integrated system without observing ideological and value principles can destructively affect the general cultural climate of the society.

Secondly, not every person is able to consciously perceive the architectural structure and understand its impact on himself (herself). Most often, the architecture is perceived by an ordinary man in the street as something taken for granted, as space of everyday life and nothing more. This does not mean that from this architecture has less effect on humans, but the effect may be much higher, if this effect is realized by people: "The first thing you must mention is aesthetic, more precisely ethical \& aesthetic conditionality of any architectural solution, including educational space. Valuable determinants not only play an important role, but are woven of many elements that have appeared at different times and formed an organic integrity, often consequential of each other. Being inside of it since one's birth, man is able to identify without further reflection its phenomena as "their", "close", "understandable". Human does not have to articulate them, whereas for a representative of another social and cultural environment they need to be deciphered, compared with the already known information (in the spirit of "it's like ...”), etc.” (T.Yu. Bistrova, 2010, 130).

\section{Methods}

Methodological core of the present study are the modern cultural and sociological ideas about the nature and methods of forming cultural identities represented in the works of F.J. Schwartz, K.M. Kuenzli, E.G. Grossman, C.M.S. Johns, O.N. Afanasieva, T.Yu. Bistrova, Yu.R. Gorelovoi, O.E. Zhelezniak, G.Yi. Okhrimenko, O.A. Zhukova, D.A. Leontiev, A.A. Nikonova, M.V. Puchkov and modern works on the essence of cultural identities of the regional level as well (N.A. Galaktionova, 2010; 
E.V. Golovneva, 2013; E.E. Dutchak, E.L. Lvov, 2012; G.S. Korepanov, 2009; D.S. Kotelnikov 2009; V. Sukhanov, 2009; K.E. Tumakova, 2010). Cultural studies revealed the potential of works of architecture based on the methods of the modern theory of fine arts by V.I. Zhukovsky (V.I. Zhukovsky, 2011; V.I. Zhukovsky, N.P. Koptseva, 2010), as well as on the basis of methodological developments of employees of the Department of Cultural Studies at the Institute of Humanities, Siberian Federal University in the study of the regional cultural identity in the material of the analysis of cultural and artistic artifacts (Yu.S. Zamaraeva, 2010; N.P. Koptseva, N.N. Nevolko, 2012; N.M. Libakova, 2011; V.S. Luzan, 2013; K.V. Reznikova, 2013; A.A. Semenova, 2012; E.A. Sertakova, 2010, 2013).

\section{Basic Concepts}

Based on the guidelines described in the introduction we can stipulate the following qualitative properties of a piece of architecture, understood as the space of the viewer interaction and architectural material, i.e. the space of an architectural art image, according to the modern cultural and semiotic theory of art by V.I. Zhukovsky (V.I. Zhukovsky, 2011; V.I. Zhukovsky, N.P. Koptseva, 2010).

Architectural artistic image is an artistic image, which is being created and developed during the time of relationship of the viewer and the architectural work-substance. Its specific qualities come from the special qualities of all its "parents": art material, architect, work-item, and viewer.

Architectural artmateriali.e. the construction blocks from which an architectural worksubstance is created. Its main characteristics: maximum proximity to nature, primary limiting unconditionality and unlimitedness, strength, durability, exclusivity in relation to others, beauty, comfort for human use in accordance with the natural conditions, constructive techniques and functions of the masterpiece-substance.

The architect is the creator of the architectural work, a person who by the transformation through natural space creates sensuously given phenomena-venue for a meeting between man and infinity in its various aspects and models in a material way to the spatial composition of this meeting, in this way, solves the extremely important task. Required distinctive qualities of an architect: visual spatial thinking, rational logic combination of building techniques and intuitive artistic thinking, possession of knowledge of many industries (civil engineering, history of art, math, physics, composition, psychology), artistic taste and talent to create works of architecture like the demiurgic act of creation of the world (the building as a universe).

Thearchitecturalwork-substanceis amaterial cover of the architectural masterpiece, it exists at the interface of natural and artificial: is being created by the architect from natural materials in the environment, but by the man and for the man. Distinctive features of the architectural worksubstances are as follows: quality functionality, spatial volume, reality of mass volumes, surfaces and rhythms of light and shade, strength, spatial extent, the importance of interaction with the environment, the interaction of exterior and interior, structural and compositional integrity similar to human body, ordering, the availability of force fields to lead the viewer, suggesting a dynamic dialogue, the ability to really plunge the viewer into the artistic space.

The viewer of an architectural work is the one who is not only a spectator, but also a "user" of the masterpiece-thing, that is the one who was originally contracted by its functional tempt. The following qualities are important for the viewer of an architectural work: developed spatial thinking, personal experience, 
significantly affecting the architectural image, the ability to rationally comprehend sensual data and irrational experience, the ability to be driven by force fields of the architectural masterpiece-thing and to realize the content of architectural forms in a dynamic dialogue, participating in the formation of a multi-level architectural image.

Works of architecture can be divided into different types, based on the functionality of architectural work-things that act as material shells for the works of architecture: public, worship, public secular, private secular works. Functionality of the architectural work-thing becomes of secondary importance when the architectural artistic image activates its "superfunction" aimed at the harmonization of human life and gives a sensual way of gaining manifest unity with the Fullness of Life.

\section{The Analysis of Krasnoyarsk Church of the Miracle of Archangel Michael at Chonae}

One of representatives of church architecture at the regional level can be the Church of the Miracle of Archangel Michael at Chonae, designed by the architect Konstantin Yu. Shumov and Yury V. Tikhonovich in $2000-2003$ in Krasnoyarsk (micro-district Vetluzhanka). Finishing works continue up to this day.

Already at the observation level the church clearly lets the viewer understand that this is special space by contrasting to surrounding buildings. The observer from afar notices a building located on a hill, all forms aspiring to the sky and its general shape, fit into a triangle pointing up (mainly due to the tent-shape). In addition, the church space is surrounded by a wall, delimiting the church from ordinary buildings surrounding streets and wastelands. The church fence forms a yard square. The entrance is shaped as a massive gate decorated with arched openings - a narrow side, the daily arrival - and a wide central - for holidays. The church, raised on a hill, is surrounded by a circular track for a round-trip. The church is white, the tent cover is blue, and the domes are traditionally gold. The observer can see many architectural, forwarded up elements turrets of the fence, keeled gable heads, four rows of keeled corbel-arches at the bottom of the tent, the tents themselves (the large and the small one over the bell tower), onion domes, slit windows, easy-columnar frieze directed diagonally to the facades . Everything points to the single center - the tent cross. However, there are some elements that, in contrast, are directed downwards - the entrance arch, the final parts of the arched windows, right angles of the body, the columnar belt of the tent. The path around the hill on which stands the church, takes the observer in the round trip, which he (she), coming from afar to the church may have already made speculatively. Bypassing the church, the viewer sees numerous decorative niches in the form of crosses or ornamental belts that he (she) wants to examine thoroughly, but they are fairly high off the ground. The apse with three-bay gables keeled in the middle, like the rest of the facades has three slit-like windows and slightly protrudes from the body of the church. Semi stairs with each facade (except Eastern) powerfully call the viewer to climb over them and to go inside. Particularly strong influence of the western facade, with which the viewer begins to chat - after passing through the gate, he (she) sees the stairs, aimed directly at him (her), hugging and summoning up to be closer to the brilliance of the bell tower. About at this point the viewer becomes a companion and enters into a meaningful dialogue with the church. Utilitarian functionality of the church as a place to communicate with God is remembered by the spectator and observer and is important - 
otherwise he (she) would have been unlikely to come.

At the stage of initial contact the viewer comprehends everything he (she) saw. Comparing the church with the surrounding houses and empty space around, the viewer understands the feature of this place as sacred - it is a detached fence separating the profane from the sacred. The square church fence protects the temple from prying eyes and protects against the ingress of all those who did not come for a prayer. Its shape (a symbol of the final, the human world) clearly delineates the boundary beyond which the believer needs to leave his (her) everyday thoughts. The inner courtyard with a temple walkway encircling the inviting and embracing the stairs - for those whom the Church awaits for the true believers who came to communicate with God.

The ceremonial white body of the temple (sacredness, conviviality, purity) in conjunction with the blue tent (color of the sky, a symbol of divine and spiritual) and gold domes (sun symbol of divinity and radiance of holiness) builds a common understanding of the temple as God's home.

The viewer interlocutor, reflecting about naming the temple - the Church of the Miracle of Archangel Michael at Chonae, - knowing Christian history, you wonder why the temple was dedicated exactly to this holy event. The main motive of the history of the Miracle of Archangel Michael at Chonae - the appeal of the Gentiles to faith in Christ - the sick healed, the wrong turn to faith, seeing the miracle. The power of prayer creates an impossible believer (prayer Archippus to Archangel Michael, yawning hill to avoid the destruction of the temple). Vetluzhanka - a new district of Krasnoyarsk, quite remote from the center, mainly built up with different-sized houses. The construction of the temple, on the one hand, is a missionary mission, like the story the Miracle of Archangel Michael at Chonae - to draw people to faith - that now is a pretty important issue. On the other hand, it enables a person, mired in the mundane (boring gray house), rise above it and experience the miracle of transformation in faith. Functionality is directly associated here with super-functionality of masterpieces of architecture.

Embossed facade elements (in the form of crosses, niches and rows of fancy), penetrating the body of the temple, buried, and inviting the viewer to dive deep into yourself. In addition, this confessional orientation show cosmocentric aspects of the religious masterpiece - that Christian faith can give a person what he (she) wants.

The triangular shape of the church, striving numerous architectural characters up, color and location of the church on the hill ("over" the bustle of everyday life) forms the viewer-companion a visual concept as "the mountain world" (association of children with a mountain, a mountain in the very mention of the history of the Marvel). It is both divine and location (house of God), and visible "way" in the mountain lands for the viewer, as a kind offer to experience the wonder of the soul and to find yourself speculatively in the mountain world.

Aspiring up forms of the church, promising peace soaring from afar, complemented by architectural characters that represent the outpouring of divine dictate blessings. This interaction is important for regional architecturebasically, all the temple work have city dictate direction. Accordingly, a person who at the turn of $20^{\text {th }}-21^{\text {st }}$ centuries experienced a deep crisis in different spheres of life, you need to find a space where you can turn to God for help, and not just silently listen to divine guidance - and the architecture responds to this desire. For example, the powerful gate fence invite you to 
enter and the arches "pour out" its grace on the viewer, purifying him (her) from the bustle of everyday life, so that he (she) becomes prepared to communicate, so when surpassing the border, he (she) was already free and the temple could easily drew him (her) to the enthusiastic impulse.

Stepping up the stairs, the audience rises above ground level - it is a sign that should rise from all earthly things, of course, apply to the spiritual. The bell tower with the dome, through which the viewer enters the temple marks a small triumph of the human soul, which came to a festive meeting with the divine.

Getting into the interior of the church, the audience at the observation level captures all focus on the single center space - the space under the tent. It is noted with a huge golden candelabra of the censers located directly under the dome. All elements call the eye to look up into the dome. Also, the viewer sees a wooden iconostasis with royal doors, hiding the apse. The temple murals also contribute to the concentration on the single center.

At the level of interaction the entire gathering of the space around the center and upward continues the tendency of the line of shown in the exterior appearance of the masterpiece. Handling up - it is a prayer of the believer, which the temple carefully directs to the sky, to the very dome-axis along the way, which is partially revealed by the rich golden candelabra. The window focuses light exactly on the tent-space. The candle candelabra is a symbol of faith burning, an architectural metaphor for the need for the viewer to burn and to be spiritually aspiring to heaven, so that the miracle of transformation from a profane human to spiritual human could happen.

Thus, the Church of the Miracle of Archangel Michael at Chonae belongs to the type of architecture, which can be defined as a masterpiece of church architecture mainly the enthusiastic trend capable of forming a positive cultural identity of regional, national and cultural level.

\section{Experimental Testing of Research Results}

Based on the above theoretical propositions identified, as well as relying on the analysis of the Krasnoyarsk Church, it was decided to conduct a practical study of the peculiarities of perception of architectural works of younger and older school-age children to identify their perceptions of the product of architecture and its properties.

The experiment involved 90 children aged 9 to 11 years from four cities of Russia, as well as a group of teenagers of 24 people aged 13 to 17 years from Krasnoyarsk.

Implementation of the experiment took place in two stages.

The first part of the experiment took place in the form of tutorial session, discussions on the subjects:

1) Oral talk on the topic "What is architecture?" How the architecture is different from sculpture, from painting?", "What is a masterpiece of architecture?".

2) Practical testing of hypotheses of children, what is a masterpiece of architecture, and how is it different from a simple building. The practical definition was given on the material of the world and Krasnoyarsk representatives of architecture and everyday ordinary buildings.

3) Consideration of the masterpiece of architecture "Pantheon" in the form of oral questions and simultaneous demonstration of its images from different angles, the external appearance and interior. The result of the discussion was the conclusion about the purpose and ideological features of the masterpiece of architecture. 
The second phase took place in different forms, depending on the age of the children:

1) for the younger group in the form of a quest-game within the space of the city of Krasnoyarsk: a task aimed at seeking masterpieces of architecture in the city of Krasnoyarsk and their comparison with conventional buildings in the form of tables;

2) for the older group in the form of an independent analysis of works of architecture in Krasnoyarsk from reproductions, digital images and video, where the main task was to identify the correspondence between the function of the works of architecture and their external and internal forms.

Interpretation of the results of the research was based on the frequency and uniqueness of the children's responses. We can draw the following conclusions on the representations of the primary school children about the works of architecture:

1. The concepts of the children on architecture and its properties are based on their personal experience: their direct communication with architecture (primarily their own home, then public buildings in which they had been theaters, museums, circuses), seen photos and pictures, read articles in children's encyclopedias (e.g. ancient writings).

2. Architecture is a special kind of art, the result of which are buildings constructed according to a unique drawing that have already been made (produced).

3. A building having the following features may be called a masterpiece of architecture: beauty, uniqueness, unusual appearance, complex structure in which each part has its place, harmonious proportions, a specific order, the accompanying entourage, the memory of something important, social significance.

4. The masterpiece of architecture should express an idea and is designed to be something special, important to people ("that is why they are constructing it, and that is why the masterpiece of architecture is different from nature, and from a usual house").

5. Masterpieces of architecture are special places for people to be together, where people go to do something together (theater, museum, temple). These structures are not constructed as a protection from the weather, but as a place to experience special feelings. The masterpiece of architecture makes people experience special emotions while when looking at an ordinary building no special feelings are to be found.

6. A railway station or even an ordinary house can be a masterpiece of architecture if it has its features.

7. Light plays an important role in the architectural masterpiece, making the space of the building magically lit, special.

Initially, the children did not use the phrase "a masterpiece of architecture". Meaning it, they often used the word "monument", "special building". By the end of the experiment after passing the practical part of the children in the city, many people began to use it often, even in the conversation for another task, for example, about the features of an architectural ensemble: "The architectural ensemble must necessarily consist of only masterpieces of architecture".

Interpreting the results of responses of the older children, we may highlight the following aspects of their perceptions of a masterpiece of architecture, which were not found in the younger group: 
1. Masterpieces of architecture are created in the creative process: there is the architect's design, there is a special material that the architect chooses carefully, and finally, there is the masterpiece itself as a result of a creative act.

2. The masterpiece of architecture belongs to a particular style of architecture, is inscribed in the general history of the development of architectural forms.

3. There are different levels of quality of masterpieces of architecture, which are more or less close to the recognized masterpieces.

4. There are special techniques in decorating architectural masterpieces - they need to be decorated, but they may not be beautiful, it is not the most important.

5. By the appearance of architectural forms people can understand what for the masterpiece has been created and what are its ideological features

The key finding of the experiment for the kids was the knowledge that the masterpieces of architecture and everyday structures differ from each other, and masterpieces of architecture in their forms conclude ideological content, which can be "read" in contrast to conventional buildings. The experiment is significant for the fact that the experience with works of art, which the kids got in a playful way, can be transferred to those works, with whom they interact in reality. In addition, they now began to perceive them as works of art by their own grounds thus opening an opportunity to "inscribe" the masterpieces of their native hometown into the history of the world art by "reading" in their forms its ideological content and determining how close they are to architectural masterpieces. Such an understanding of architectural works is fundamentally different compared to the one which existed prior to the experiment.

\section{Conclusion}

Thus, the practical study confirmed expressed theoretical guidelines by supporting with the real experience of interaction of children with various architectural structures and spaces. It is obvious that the greatest number of positive emotions and the most significant interest in children was raised by architecture as a special kind of fine arts. It is important to note the positive effect of the architectural mapping - comparison of architectural monuments of world importance with works of architecture at the regional level, which leads not only to increased interest in its own built environment, but also the degree of awareness when interacting with specific works of architecture in ordinary everyday life. It is this way allows you to create a positive cultural identity at the regional level, which is able to fit harmoniously into all-Russian and the general cultural level.

These results confirm that the research is important and promising with relation to further search of the principles and characteristics of the impact of architecture on the cultural identity of the person.

\section{References}

1. "New Architecture" at the XX International Festival of Architecture "Architecture" (2013) Housing, 1, 17.

2. Alcala, L.E. (2012) "A Call to Action": Visual Persuasion in a Spanish American Painting. The Art Bulletin, 94 (4), 594-617.

3. Blakesley, R.P. (2010) Pride and the Politics of Nationality in Russia's Imperial Academy of Fine Arts, 1757-1807. Art History, 33 (5), 800-835. 
4. Boettger, S. (2012) This Land Is Their Land. Art Journal, 71 (4). doi: http://artjournal. collegeart.org/?p=3566\#sthash.mojAR0Yv.dpuf

5. Fluck, W. (2012) Transatlantic Narratives about American Art: A Chapter in the Story of Art History's Hegelian Unconscious. Art History, 35 (3), 554-573.

6. Grossman, E.G. (1996) The Civic Architecture of Paul Cret (Modern Architecture and Cultural Identity), $300 \mathrm{p}$.

7. Higa, K. (2013) A Collage of Remembrances.Art Journal, 72 (3). doi: http://artjournal. collegeart.org/?p=4256\#sthash.URnfR60J.dpuf

8. Johns, C.M.S. (2004) Portraiture and the Making of cultural identity: PompeoBatoni's the Honourable colonel William Gordon (1765-66) in Italy and North Britain. Art History, 27 (3), 382-411.

9. Kavaler, E.M. (2006) Renaissance gothic: pictures of geometry and narratives of ornament. Art History, 29 (1), pp. 1-46.

10. Kitnick, A. (2012) Another Time. Art Journal, 71 (2). doi: http://artjournal.collegeart. org/?p=3093\#sthash.zd4lRgws.dpuf

11. Kuenzli, K.M. (2012). Architecture, Individualism, and Nation: Henry van de Velde's 1914 Werkbund Theater Building. The Art Bulletin, 94 (2), 251-273.

12. Kunimoto, N. (2013) Gutai's Ascent. Art Journal, 72 (2). doi: http://artjournal.collegeart. org/?p=3982\#sthash.EF1wdtMB.dpuf

13. Maciuika, J.V. (2005) Before the Bauhaus: Architecture, Politics, and the German State, 1890-1920 (Modern Architecture and Cultural Identity).

14. Mathur S. (2011) Charles and Ray Eames in India.Art Journal, 70 (1). doi: http://artjournal. collegeart.org/?p=1735\#sthash.QrPtty9t.dpuf

15. Pepe, S. (2011) Craft Class. Art Journal, 70 (2). doi: http://artjournal.collegeart. org/?p=2137\#sthash.sNmaE00A.dpuf

16. Reeve, M.M. (2013) Gothic Architecture, Sexuality, and License at Horace Walpole's Strawberry Hill.The Art Bulletin, 95 (3), 411-439.

17. Schumacher, P. (2009) Parametricism - A New Global Style for Architecture and Urban Design. Architectural Design - Digital Cities, 79 (4).

18. Schwartz, F.J. (2012) Architecture and Crime: Adolf Loos and the Culture of the "Case". The Art Bulletin, 94 (3), 437-457.

19. Scott, K. (2005) Framing ambition: The interior politics of MME de Pompadour. Art History, 28 (2), 248-290.

20. Shannon, J. (2012) We Are Pop People. Art Journal, 71 (4). doi: http://artjournal.collegeart. org $/$ ? $\mathrm{p}=3560$ \#sthash.XuqFUjoX.dpuf

21. Singh, D. (2013) Indian Nationalist Art History and the Writing and Exhibiting of Mughal Art, 1910-48. Art History, 36 (5), 1042-1069.

22. Smith, T. (2010) The State of Art History: Contemporary Art. The Art Bulletin, 92 (4), 366383.

23. Swetnam-Burland, M. (2010) AegyptusRedacta: The Egyptian Obelisk in the Augustan Campus Martius. The Art Bulletin, 92 (3), 135-153.

24. Terry, A. (2010) Criminals and Tourists: Prison History and Museum Politics at the Bargello in Florence. Art History, 33 (5), 836-855. 
25. Thomas, G.M. (2009) Yuanming Yuan / Versailles: intercultural interactions between Chinese and European palace cultures. Art History, 32 (1), 115-143.

26. Whiting, C. (2011) David Hockney: A Taste for Los Angeles. Art History, 34 (4), 858-874.

27. Zimmerman,C. (2012) Photography into Building in Post-war Architecture: The Smithsons and James Stirling. ArtHistory, 35 (2), 270-287.

28. Agishev, S.T., Mubarakshina, F.D. (2013) Problems of development of modern architecture in the historical environment of the city. Proceedings of the Kazan State University of Architecture and Construction, 4 (26), 7-15.

29. Alexeev, S.Y., Alekseeva, N.N. (2013) theory of spatial scales and cultural polyphony in architecture. Housing, 2, 19-20.

30. Aronov, V.R. (2011) Theory of designing by Thomas Maldonado. $20^{\text {th }}$ of the $21^{\text {st }}$ century. Design problem-6, 20-23.

31. Astafieva, O.N. (2010) Restructuring and demarcation of collective identities in the context of globalization: the future of national and cultural identity. Questions Social Theory, 4, 255-281.

32. Biryukov, E.E. (2009) The terms "architecture" and "architectural space" in the context of the many aspects of architecture as a phenomenon. Collection of scientific works Sworld, 28 (1), 52-59.

33. Bystrova, T.Y. (2008) Oriental philosophy as the basis of ecological architectural thinking: harmony - integrity - health. Academic Gazette Ural Research Institute project RAASN 1.

34. Bystrova, T.Y. (2010) The implementation of cultural identity in architectural space education: universities of China. International Journal of Cultural Studies, 1.

35. Vetoshkin, V.I. (2010) The dialectics of knowledge architecture. Architecton Journal, 32. Available at http://archvuz.ru/2010_4/7.

36. Vityuk, E.J. (2012) Architectural Synergetics: preconditions for the emergence of a new paradigm. Architecton Journal, 37. - Mode of access: http://archvuz.ru/2012_1/6.

37. Vlasov, VG (2013) Design and architecture of XXI century. Architecton Journal, 41. Available at: http://archvuz.ru/2013_1/1

38. Gavrikov, D.S. (2012) between foreign and identity: the question of development of motives half-timbered architecture in central Russia in the modern era. Architecton Journal, 38, 8.

39. Galaktionov, N.A. (2010) Features of contemporary processes of regionalization and the formation of regional identity. Regional Studies, 2, 257-264.

40. Golovneva E.V. (2013) Regional identity as a form of collective identity and its structure. Maze. Journal of Social and Humanities Research, 5, 42-50.

41. Gorelova Y.R. (2013) The image of the territory as a condition for the formation of a positive cultural identity and priority regional cultural policy. Kant: social and human sciences, 1 (1), 24-32.

42. Gromnyuk, A.I. (2012) National searches in world architecture of the nineteenth and twentieth century. Tradition and Innovation in Higher Education Architecture and Art: collection of scientific papers, 5, 120-123.

43. Gromnyuk, A.I. (2013) Conceptual principles of interior architecture in the context of ethnoart traditions, mentality and the architecture of the national property. Architecture and Modern Information Technology, 4 (25) 11.

44. Gumenuk, A.N. (2013) Modern interpretations of historical and cultural heritage: neomodern architecture Omsk. Studies in the Humanities in Eastern Siberia and the Far East, 2, 83-86. 
45. Danylyuk, A.G. (2008) The early architecture of the Ukrainian village Ethnographic essay, 256.

46. Dutchak E.E., Lvov, E.L. (2012) Siberian regional identity - a factor of conflict or resource formation of Russian national identity? Proceedings of the Irkutsk State University. Series: History, 2-1, 41-44.

47. Ironstone, O.E., Ohrimenko G.I. (2009) The spaces of cultural identification. Semey Transbaikalia: monograph.

48. Zhuikov, S.S., cold, LP (2012) Background The architecture of the future, "astro-architecture." New ideas of the new century: proceedings of the international scientific conference FAD PNU, 1, 458462 .

49. Zhukova, O.A. (2009) Cultural identity, cultural heritage and cultural policy of Russia. Knowledge. Understanding. Skill, 2, 25-30.

50. Zhukovsky, V.I (2011) Theory of Fine Arts, 496.

51. Zhukovsky, V.I, Koptseva, N.P. (2010) Art as a vital necessity. Work of art. Art and Education, $3,5-29$.

52. Zamaraeva Y.S. (2010) The relevance of the study of migrants and the receiving environment in the modern philosophy of culture. Science and modernity, 5-3, 96-100.

53. Zarubin, N.A., Meerovitch, M.G. (2013) Siberian wooden Baroque civil architecture Irkutsk $19^{\text {th }}$ century. Architecton Journal, 43. Mode of access: http://archvuz.ru/2013_3/11.

54. Ibragimov, I.A. (2009) Formation of architecture Christianity and Islam as an expression of the notion of a coordinate system in visual orientation-semantic space. Architecton Journal, 26. Available at http://archvuz.ru/2009_2/6.

55. Ignatov, A.M. (2011) "Ethnic Empire" - a new stage in the evolution of the style of architecture, the use of new materials and technologies. Architecton Journal, 34. Mode of access: http://archvuz. $\mathrm{ru} / 2011 \_2 / 15$.

56. Ismagilov, N. (2009) The problem of regional identity in the Russian socio-cultural space. Geography and Natural Resources, 3, 129-134.

57. Karovskaya V.O. (2012) Architecture of the educational environment as a matter of historical and cultural studies. Yaroslavl Pedagogical Gazette, 1 (4), 270-271.

58. Kelly, K. (2011) Making a Home on the Neva: domestic space, memory, and local identity in Leningrad and St. Petersburg, 1957 - present. Laboratorium. Journal of Social Research, 3, 53-96.

59. Kirko, V.I., Verkhovets, S.V., Keush, A.V. (2010) The role of federal universities in the formation of regional innovation structures (for example, Siberian Federal University). Innovation, 10, p. $60-64$.

60. Kirko, V.I. Zakharov, K.N. (2013) Traditional economic activities - ethnos keeping lifestyle. Arctic and North, 12, 24-31.

61. Koptseva, N.P., Luzán, V.S. (2012) National cultural policy in the Siberian Federal District: concepts, issues, research: Monograph.

62. Koptseva, N.P. (2002) Introduction to Aletology.

63. Koptseva, N.P. (2013) Truth in Plato's philosophy. Philosophy and Culture, 4, 429-436.

64. Koptseva, N.P. (2013) The problem of truth in the philosophy of religion. Specificity conceptualization of truth in Buddhist philosophy. Philosophy and Culture, 11, 1564-1573. 
65. Koptseva, N.P. (2000) Philosophy and Arts: the unity of the thinking space. Memoirs of the Faculty of Arts and Cultural Studies, Issue 1.

66. Koptseva, N.P. (2007). Integration of liberal education in the Siberian Federal University. Higher education today, 4, 6-8.

67. Koptseva, NP (2007). Theory and practice of innovative educational programs for aesthetic cycle disciplines. Higher Education Today, 12, 9-13.

68. Koptseva, N.P. (2012). The cultural base of the all-Russian national identity formation in the Siberian region of the Russian Federation. Bulletin of Volgograd State University. Series 7. Philosophy, sociology and social technologies, 3, 11-15.

69. Koptseva, N.P. (2012). Methodological possibilities of social (cultural) anthropology to contemporary cultural studies. Philosophy and Culture, 10, 9 -18.

70. Koptseva, N.P. (2012). The problem of methodology for Contemporary Cultural Studies: Opportunities classic British social anthropology. Humanities and Social Sciences, 4, 89-104.

71. Koptseva, N.P. (2013). A pilot application of cultural studies Intercultural Communication: focus groups, personal interviews, questionnaires, obtaining expert opinion (based on the study of the Krasnoyarsk Territory). Modern Problems of Science and Education, 3, 410-410.

72. Koptseva, N.P., Libakova, N.M. (2013). Productivity gender approach for humanitarian studies. Modern problems of science and education, 1.

73. Koptseva, N.P., Nevolko N.N. (2012). Visualization of ethnic traditions in painting and graphic works Khakassian masters. Art and Education, 1, 27.

74. Indigenous peoples of the North and .Siberia under the global transformations (on the basis of the Krasnoyarsk Territory). Part 1. Conceptual and methodological bases of research. Ethno-cultural dynamics of Indigenous Peoples of the Krasnoyarsk Territory: Monograph (2012) / A.E. Amoz, Koptseva N.P. Libakova N.M., Reznikov K.V. Sertakova K.V. Pimenova N.N. Kistova A.V. .et al. Ed. N.P. Koptseva, 640.

75. Korepanov, G.S. (2009) Regional identity as a basic category of sociology regional development. Power, 1, 43-50.

76. Kotelnikov, D.S. (2009) Regional identity: the social nature and features of the formation in Russia. Humanitarian and socio-economic sciences, 5, 105-109.

77. Krivonogov, V.P. (2007) The peoples of Taimyr at the beginning of the $21^{\text {st }}$ century.

78. Culture of indigenous peoples in the context of global transformations: Monograph (2011) / N.P. Koptseva, E.A. Sertakova, M.I. Ilbeykina Y.S. Zamaraeva, N.M. Libakova, V.S. Luzán etc. / edited by. N.P. Koptseva, 174.

79. Lamech, N.V. (2009) The psychology of perception as a factor in shaping the architecture of preschools. Architecton Journal, 28. Mode of access: http://archvuz.ru/2009_4/2.

80. Leontiev, D.A. (2009) Labyrinth identities: not man for the identity and the identity of human. Philosophical Sciences, 10, 5-10.

81. Libakova, N.M. (2011) Modifications of gender images in the Russian culture of the end $19^{\text {th }}$ - beginning of $21^{\text {st }}$ century.: The dissertation ... The candidate of philosophical sciences: 24.00 .01 , 155 .

82. Lobanov, A.V. (2008) The perception of architectural space and architectural environment in modern architecture. Architecton Journal, 23. Mode of access: http://archvuz.ru/2008_3/1 
83. Luzán, V.S. (2013) Contexts understanding intellectual leisure in modern Russian studies. Bulletin of the Krasnoyarsk State Pedagogical University of V.P. Astafiev, 4 (26), 175-178.

84. Luzán, V.S. (2011) Socio-philosophical analysis of the dynamics of the state cultural policy of the Russian Federation: the dissertation ... The candidate of philosophical sciences: 09.00.11, 170.

85. Mityashin, NA Kontsetsiya dynamics of architectural space in today's society. Available at http://book.uraic.ru/project/conf/txt/005/archvuz18_pril/29/template_article-ar=K21-40-k39.htm

86. Monakhova, L.P. (2011) Style priorities and culture of everyday reality in the project thought the second half of XX century. Design problem-6, 56-57.

87. Moskaluk, M.V. (2010) All that is in my heart. Artists of Krasnoyarsk yesterday, today and tomorrow.

88. Nesterov, T.P. (2010) "Mediterranean identity": the culture and architecture of Italy in North Africa of the 1920s - 1930s. Proceedings of the Ural Federal University. Series 1: Problems of Education, Science and Culture, 75 (2), 99-210.

89. Nikitin, I.E., Shtompel, L.A. (2011) Dynamics of the historical and cultural essence of the person in the context of European architecture. Humanitarian and socio-economic sciences, 2, 55-60.

90. Nikonov, A.A. (2009) Cultural heritage and identity formation. Bulletin of St. Petersburg University. Episode 6: philosophy. Jurisprudence. Politics. The right. International Relations, 2, 203209.

91. New Future Siberia expectations, challenges, solutions: Monograph (2013) / N.A. Bakhova, A.V. Bukharov, E.A. Viktoruk, M.I. Ilbeykina etc. / edited by O.A. Karlova, N.P. Koptseva.

92. Panofsky, E. (2009) Studies on iconology, 430.

93. Permilovskoe, A.B. (2011) Cultural meanings of folk architecture of the Russian North. Yaroslavl Pedagogical Gazette, 1 (2), 291-297.

94. Pozdnjakova, O.A., Reznikov, K.V (2013) Features of artistic subjects of cinema communication. Modern problems of science and education, 4, 385.

95. Puma, P. (2012) Documentation of architecture and the environment: an overview of technology study and promotion of cultural heritage. Bulletin of Tomsk State University. Cultural and Art Criticism, 1, 70-79.

96. Puchkov, M.V. (2013) Globalization and Identity in the architecture of modern cities. Proceedings of the Ural Federal University. Series 1: Problems of Education, Science and Culture, 116 (3), 140-147.

97. Reznikov, K.V. (2013) Value for the formation of the All-Russian cinema national identity. Modern Problems of Science and Education, 3, 416.

98. Reznikov, K.V. (2012) The Social Construction of national identity in the Russian Federation: the author's dis. ... The candidate of philosophical sciences: 09.00.11, 20.

99. Sembin, M.S. (2013) Digital architecture as a new approach to the formation of modern architecture. Priority research areas: from theory to practice, 8, 7-11.

100. Semenov, A.A. (2012) Visual Culture of modernized society / Bulletin of Volgograd State University, Series 7. Philosophy, sociology and social technologies, 3, 141-149.

101. Semenov, A.A., Gerasimov, A.A. (2013) Features of the creative method of Sergei Anufriev. Modern Problems of Science and Education, 2, 542. 
102. Semenov, A.A. (2009) Modifications of ancient concept of "state" in Russian culture of the $21^{\text {st }}$ century: methodological aspect: the dissertation ... The candidate of philosophical sciences: 24.00.01, $198 \mathrm{p}$.

103. Sertakova, E.A. (2013) Study of "city" in the classical concepts of foreign scientists. Modern problems of science and education, 4, 381 .

104. Sertakova, E.A. (2012) Cultural geography of A. Lefebvre in the light of humanitarian researches of social space of the city. Theory and Practice of Community Development, 3, 24-26.

105. Sertakova, E.A. (2010) Operation of art on the Internet. Science and modernity, 3-1, 64-68.

106. Sukhanov, B. (2009) Regional identity in the context of globalization: a theoretical analysis. World Economy and International Relations, 1, 104-110.

107. Talypov, D.V. (2009) The development of "game concept" space in architectural theory. Architecton Journal, 28. Available at http://archvuz.ru/2009_4/9.

108. Tokarev, A.S. (2006) Study the possibility of saturation of the cultural content of architectural space. Architecton Journal, 14. Available at http://archvuz.ru> 2006_22/49

109. Tolstikova, I.I. (2012) Contamination of cultural meanings in the architecture of the twentieth century. Bulletin of the Leningrad State University A.S. Pushkin, 2 (3), 127-136.

110. Tumakova, K.E. (2010) Regional identity and branding as social resource management. Power, 3, 70-73.

111. Kholodova, L.P. (2010) Concepts of modern architectural theory. Architecton Journal, 31. Available at: http://archvuz.ru/2010_3/1.

112. Chabbarov, B.C. (2011) National-cultural trends in modern design and architecture. Proceedings of the Ural Federal University. Series 1: Problems of Education, Science and Culture, 92 (3), 201-206.

113. Chernat, V.A. (2013) The King: the doctrine of national identity of Belarusian architecture. Architecture. Building. Design, 3 (72), 63-69. 


\title{
Архитектурное пространство
}

\section{как фактор региональной культурной идентичности}

\author{
А.В. Кистова, А.Н. Тамаровская \\ Сибирский федеральный университет \\ Россия 660041, Красноярск, пр. Свободный, 79
}

Представленные в статье положения основываются на выводах современных культурологических и искусствоведческих исследований о способности архитектурных пространств формировать у человека, взаимодействующего с ними, представление о себе, об обществе, о мире. Только истинные архитектурные творения уровня произведения искусства способны оказыватьблаготворное воздействие на культурную идентичность человека в прочессе формирования архитектурного художественного образа. В статье также представлень результать исследования красноярской Церкви Чуда Михаила Архангела в Хонех в качестве репрезентанта произведения храмовой архитектуры регионального значения, способной формировать положительную культурную идентичность, и итоги практических исследований особенностей восприятия архитектуры детьми младмего и старшего школьного возраста, проведенных студенткой четвертого курса направления «история искусств» Гуманитарного института Сибирского федерального университета Анастасией Тамаровской.

Ключевые слова: региональная культурная идентичность, архитектурное пространство, произведение архитектуры, архитектурный художественный образ, восприятие архитектуры детьми, красноярская архитектура, Церковь Чуда Михаила Архангела в Хонех.

Научная специальность: 24.00.00-культурология, 17.00.00-искусствоведение. 